\title{
Synthesis, structural characterization and properties of aluminum (III) meso-tetraphenylporphyrin complexes axially bonded to phosphinate anions
}

\author{
Sébastien Richeter, ${ }^{,{ }^{\dagger}}$ Julien Thion, ${ }^{\dagger}$ Arie van der Lee, ${ }^{\ddagger}$ Dominique Leclercq ${ }^{\dagger}$ \\ Laboratoire de Chimie Moléculaire et Organisation du Solide, UMR 5637, Université Montpellier II, \\ CC 007, Place Eugène Bataillon, 34095 Montpellier Cedex 05, France, and Institut Européen des \\ Membranes, UMR 5635, Université Montpellier II, CC 047, Place Eugène Bataillon, 34095 \\ Montpellier Cedex 05, France.
}

RECEIVED DATE (will be automatically inserted after manuscript is accepted)

Aluminum (III) meso-tetraphenylporphyrins axially bonded to phosphinate anions have been synthesized and characterized by NMR and UV-visible spectroscopy, single crystal $X$-ray diffraction and $\mathrm{FAB}^{+}$mass spectrometry. According to the solvent, these compounds are able to self-assemble in two different manners.

A self-assembly process can be described as $a$ spontaneous association of molecules under equilibrium into stable aggregates held together by non-covalent bonds. ${ }^{1}$ Such phenomena are frequent in biological systems and an outstanding example is provided by bacteriochlorophyll molecules. ${ }^{2}$ Metalloporphyrins are attractive compounds for the design of self-assembling chromophores. ${ }^{3}$ The axial coordination on the metal center is a powerful synthetic way to synthesize large multiporphyrinic systems. ${ }^{4}$ Actually, much attention have been paid to porphyrin containing zinc(II), magnesium(II), tin(IV) or rhodium(III) as metal centers. ${ }^{5}$ Although aluminum(III) porphyrins are well known for their catalytic properties and their rich photo- and electrochemistry, ${ }^{6}$ their use as molecular building blocks for the design of porphyrin arrays remains limited. The synthesis of porphyrin arrays including aluminum (III) porphyrins is mostly limited to the use of phenolates ${ }^{7}$ and carboxylates ${ }^{8}$ as the axial ligand. Surprisingly there is no example of aluminum(III) porphyrins axially bonded to phosphinate anions.

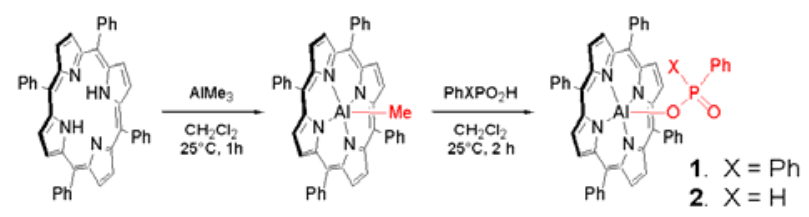

Figure 1. Synthesis of the complexes $\mathbf{1}$ and $\mathbf{2}$.

Here, we report the synthesis of aluminum(III) mesotetraphenylporphyrin ( $\left.\mathrm{Al}^{\mathrm{III}} \mathrm{TPP}\right)$ complexes axially bonded to phosphinate anions and present their properties as supramolecular building blocks. The complexes $\mathbf{1}$ and $\mathbf{2}$ were obtained by a "one-pot" strategy using the mesotetraphenylporphyrin free base $\left(\mathrm{H}_{2} \mathrm{TPP}\right)$ as starting material (Figure 1). $\mathrm{H}_{2} \mathrm{TPP}$ was treated with $\mathrm{AlMe}_{3}$ and the phosphinic acid derivative was added to the reactive intermediate $\mathrm{Me}-\mathrm{Al}{ }^{\mathrm{III}} \mathrm{TPP}$. The desired complexes $\mathbf{1}$ and $\mathbf{2}$ were obtained in high yield (85-87\%).

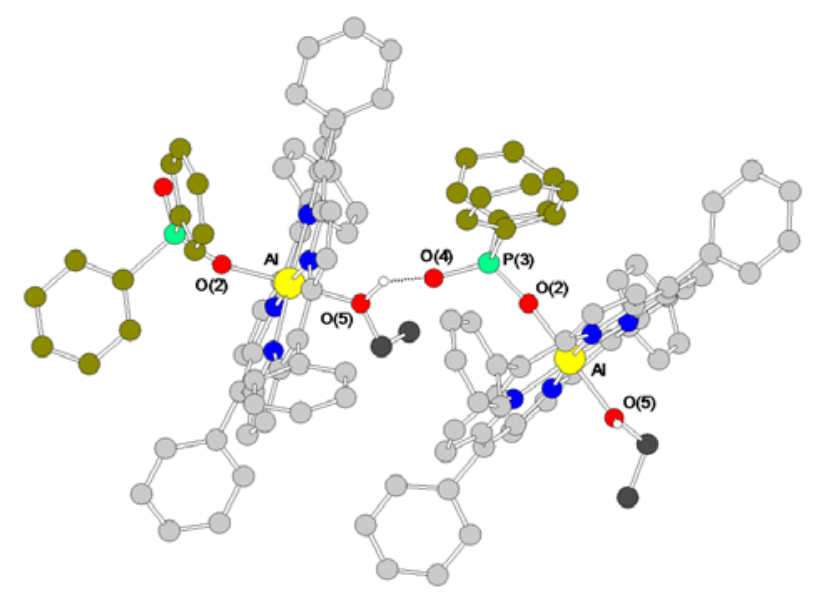

Figure 2. X-ray structure of $[\mathbf{1 . E t O H}]_{\infty}$ supramolecular chains. Light gray, $\mathrm{C}$ porphyrin; dark gray, $\mathrm{C}$ ethanol; dark green, $\mathrm{C} \mathrm{Ph}$ on $\mathrm{P}(3)$. Hydrogen atoms, except (O5)H, are omitted for clarity.

Crystals of the complex $\mathbf{1}$ were obtained by slow diffusion in pentane of a solution of $\mathbf{1}$ in a mixture of $\mathrm{CHCl}_{3} / \mathrm{EtOH}$ in a 98:2 ratio (no crystals were obtained without EtOH). This is the first X-ray structure of a $\mathrm{Al}^{\mathrm{III}}$ TPP complex axially bonded to a phosphinate anion. ${ }^{9}$ Crystallographic analysis showed that the complex 1 and ethanol molecules self-assemble to form polymeric 1- $D$ supramolecular chains $[\mathbf{1 . E t O H}]_{\infty}$, where subunits are linked through coordination and hydrogen bonds (Figure 2 ). The porphyrin is not flat but has a slight saddle shape (the $\mathrm{C} 5-\mathrm{Al}-\mathrm{C} 15$ and $\mathrm{C} 10-\mathrm{Al}-\mathrm{C} 20$ angles are close to $172^{\circ}$ ). The coordination geometry around the $\mathrm{Al}^{\mathrm{III}}$ is slightly distorded octahedral and is coordinated in the equatorial 
positions by the four nitrogen donors $\left(\mathrm{d}_{\mathrm{Al}-\mathrm{N}} \sim 2.00 \AA\right)$. One axial position of the $\mathrm{Al}^{\mathrm{III}}$ is occupied by the oxygen of the phosphinate ligand which forms a bent interaction with the metal $\left(\mathrm{Al}-\mathrm{O}(2)-\mathrm{P}(3)=161.5^{\circ}\right)$. The second axial position of the $\mathrm{Al}^{\mathrm{III}}$ is occupied by the oxygen of one ethanol molecule. The Al-O(2) distance is shorter than the Al-O(5) distance (1.86 compared to $1.98 \AA$ ). These distances are closed to those found in the literature. ${ }^{10}$ The $\mathrm{O}(2)-\mathrm{Al}-\mathrm{O}(5)$ linkage is almost linear $\left(\sim 179^{\circ}\right)$. The ethanol link the building blocks 1 together through hydrogen bonds with the $\mathrm{P}=\mathrm{O}$ functions $(\mathrm{O}(4)-\mathrm{O}(5)=2.50 \AA)$ and coordination bonds with the $\mathrm{Al}^{\mathrm{III}}(\mathrm{O}(5)-\mathrm{Al})$. The distance between two $\mathrm{Al}^{\mathrm{III}}$ atoms is $7.75 \AA$. Two views of one chain are represented in the figure $3 \mathrm{a}$. All the ethyl groups of the ethanol molecules (dark gray) are situated on the same side of the chain. Hydrophobic interactions are responsible of the packing and the chains are running parallel to the $c$ axis (Figure 3b).

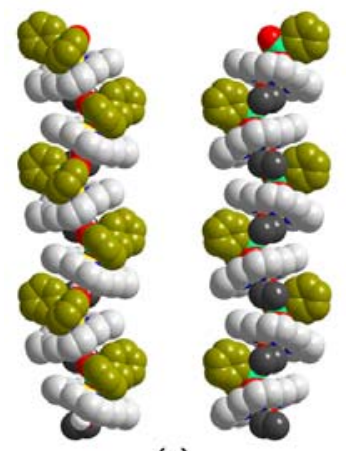

(a)

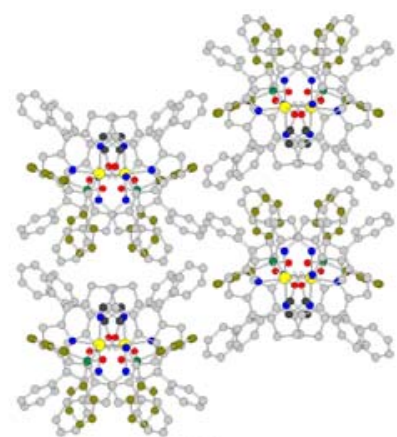

(b)
Figure 3. (a) Two different views in CPK of one [1.EtOH $]_{\infty}$ supramolecular chain. Light gray, $\mathrm{C}$ porphyrin; dark gray, $\mathrm{C}$ ethanol; dark green, $\mathrm{C} \mathrm{Ph}$ on the phosphorus atom. (Ph meso and hydrogen atoms, except (O5)H, omitted for clarity). (b) View of the crystal packing along the $\mathrm{c}$ axis (hydrogen atoms, except $(\mathrm{O} 5) \mathrm{H}$, are omitted for clarity).

The complex $\mathbf{1}$ is air and moisture stable and no dissociation of the $\mathrm{P}-\mathrm{O}-\mathrm{Al}$ bond is observed in solution even if a large excess of a coordinating solvent is added. The ${ }^{1} \mathrm{H}$ NMR spectrum of the complex 1 in a mixture of $\mathrm{C}_{6} \mathrm{D}_{6} / \mathrm{CD}_{3} \mathrm{OD}$ in a 9:1 ratio shows the axially bound phosphinate anion (Figure 4a). The characteristic signals of the TPP ligand are displayed. The three signals at 6.71, 6.54 and $4.88 \mathrm{ppm}$ are due to the protons of the phenyl rings on the phosphorus atom, respectively $\mathrm{H}_{\text {para }}, \mathrm{H}_{\text {meta }}$ and $\mathrm{H}_{\text {ortho }}$ strongly shielded by the porphyrinic ring current. These chemical shifts are close to those of a benzoate bound to a six-coordinate $\mathrm{Al}^{\mathrm{III}} \mathrm{TPP}^{8}$ In our case, the second axial ligand is a molecule of $\mathrm{CD}_{3} \mathrm{OD}$. Significant broad signals are observed by ${ }^{1} \mathrm{H}$ NMR of the complex $\mathbf{1}$ in benzene-d6 (without $\mathrm{CD}_{3} \mathrm{OD}$ ) at $25^{\circ} \mathrm{C}$ (Figure $4 \mathrm{~b}$ ). The protons resonate at higher fields showing the close proximity between the porphyrins and suggesting the formation of self-assembled species containing sixcoordinate $\mathrm{Al}^{\mathrm{III}}$. When the sample is heated at $75^{\circ} \mathrm{C}$, sharp signals are displayed corresponding to the complex $\mathbf{1}$ with a five-coordinate $\mathrm{Al}^{\mathrm{III}}$ (the $\mathrm{H}_{\text {ortho }}$ resonate at $5.20 \mathrm{ppm}$, see the Supporting Information). The addition of a coordinating solvent such as $\mathrm{CD}_{3} \mathrm{OD}$ to the NMR sample leads to sharper signals corresponding to the monomeric complex 1.CD $\mathbf{C D}_{\mathbf{3}} \mathrm{OD}$ (Figure $4 \mathrm{a}$ ). It demonstrates that $\mathrm{P}=\mathrm{O}--$ -Al interactions are involved in the self-assembled structures $(\pi-\pi$ stacking interactions are not responsible for the self-assembly process). ${ }^{11}$ This process is reversible : when solvents are evaporated and fresh benzene- $d 6$ is added, broad signals are displayed again. Sanders and co. showed that a six-coordinate $\mathrm{Al}^{\mathrm{III}}$-porphyrin complex was never detected with benzoates as the axial ligand (except if a coordinating molecule is added). ${ }^{8}$ With phosphinates as the axial ligand, six-coordinate $\mathrm{Al}^{\mathrm{III}} \mathrm{TPP}$ are observed in nonpolar solvents. The reciprocal recognition between the donor site $\mathrm{P}=\mathrm{O}$ and the acceptor site $\mathrm{Al}^{\mathrm{III}}$ leads to selfassembled structures with $\mathrm{P}=\mathrm{O}---\mathrm{Al}$ interactions.

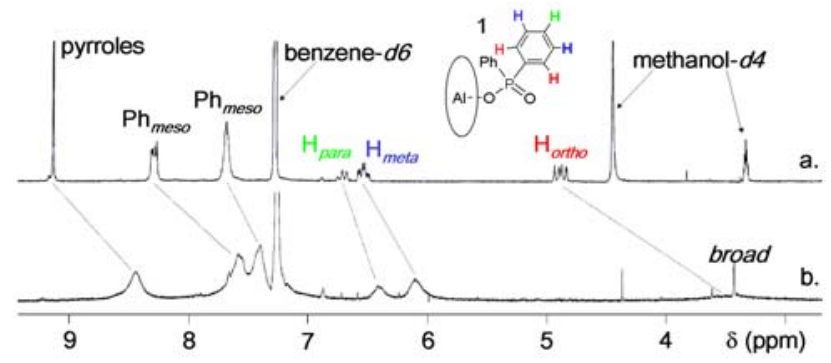

Figure 4. ${ }^{1} \mathrm{H}$ NMR spectra of $1(200 \mathrm{MHz}, 300 \mathrm{~K}, 20 \mathrm{mM})$. (a) in $\mathrm{C}_{6} \mathrm{D}_{6}+$ $10 \% \mathrm{CD}_{3} \mathrm{OD}$. (b) in $\mathrm{C}_{6} \mathrm{D}_{6}$.
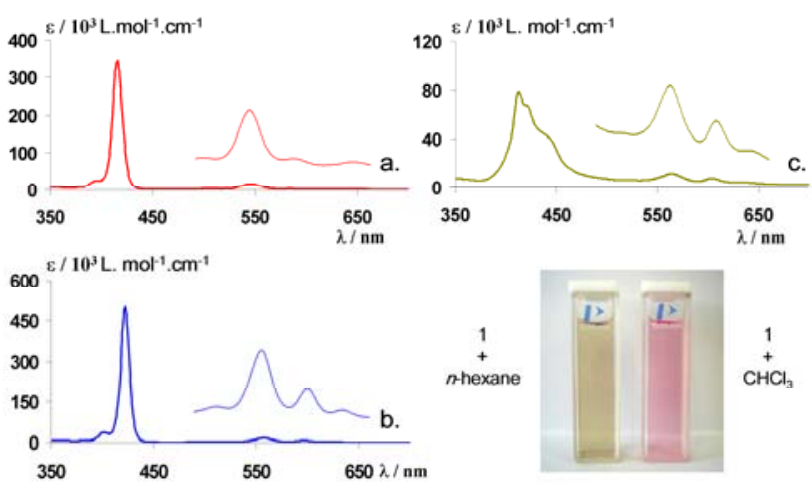

Figure 5. UV-visible absorption spectra of 1 in $\mathrm{CHCl}_{3}$ (a), $\mathrm{CHCl}_{3}+10 \%$ $\mathrm{CH}_{3} \mathrm{OH}$ (b) and $n$-hexane (c). Picture inset: quartz cells with selfassembled complex $\mathbf{1}$ in $n$-hexane (left) and not self-assembled complex $\mathbf{1}$ in $\mathrm{CHCl}_{3}$ (right) at $24 \mu \mathrm{M}$ (quartz cells of $1 \mathrm{~cm}$ path).

The self-assembly process can also be observed by UVvisible spectroscopy. A solvatochromic behavior induced by self-assembly of the complex $\mathbf{1}$ is observed. The UVvisible absorption spectrum of $\mathbf{1}$ in chloroform (Figure 5a) shows the typical absorption bands of $\mathrm{Al}^{\mathrm{III}} \mathrm{TPP}$ derivatives. According to previous studies, ${ }^{12}$ the $\mathrm{Al}^{\mathrm{III}}$ is square pyramidal $\left(4 \mathrm{~N}_{\mathrm{TPP}}+1 \mathrm{O}_{\text {phosphinate }}\right)$. No self-assembly occurs at a concentration around $10^{-5} \mathrm{M}$ in chloroform. The sharp Soret band and one intense Q band appear, respectively, at $415 \mathrm{~nm}$ and $546 \mathrm{~nm}$. When an $\mathrm{Al}^{\mathrm{III}}$ ligating entity such as methanol is added, the Soret band and the intense Q band are bathochromically shifted and appear, respectively, at 422 and $558 \mathrm{~nm}$ (Figure 5b). A second intense Q band appears at $597 \mathrm{~nm}$. This spectral evolution shows that the $\mathrm{Al}^{\text {III }}$ is octahedral $\left(4 \mathrm{~N}_{\mathrm{TPP}}+1 \mathrm{O}_{\text {phosphinate }}+1 \mathrm{O}_{\mathrm{CH} 3 \mathrm{OH}}\right)$. The recognition of the complementary polar functional parts $\mathrm{P}=\mathrm{O}$ and $\mathrm{Al}^{\mathrm{III}}$ is effective in nonpolar solvents. When a 
solution of $\mathbf{1}$ in chloroform is diluted by adding $n$-hexane, a change of color from pink to brown is observed (Figure 5, picture inset). Dramatic changes in the UV-visible absorption spectrum result from the self-assembly process (Figure 5c). The Q bands are red-shifted and show that the $\mathrm{Al}^{\mathrm{III}}$ is octahedral (two intense Q-bands at 564 and 604 $\mathrm{nm})$. The Soret band is less intense and appears split and broad. This spectral evolution arises from the excitonic coupling between the neighboring chromophores within the self-assembled structures. ${ }^{13}$ As expected, the addition of a coordinating solvent such as methanol to a solution of the complex 1 in $n$-hexane leads to complete disassembly. ${ }^{11}$

Spectroscopic analyses tend to show that the complex 1 is able to self-assemble alone in solution by $\mathrm{P}=\mathrm{O}---\mathrm{Al}$ interactions, but there is no spectroscopic evidence of the formation of oligomeric species more than the dimer. It was possible to observe by $\mathrm{FAB}^{+}$mass spectrometry a weak signal at $\mathrm{m} / \mathrm{z}=1715$ corresponding to the dimer [1] ${ }^{14}$ The exact association constant $K_{\text {assoc }}$ for this system could not be extracted, but $K_{\text {assoc }}$ for the $\mathrm{P}=\mathrm{O}---\mathrm{Al}$ interaction must be greater than $10^{5} \mathrm{M}^{-1} .{ }^{15}$ Bulky groups on the porphyrin and/or the phosphorus atom prevent the formation of stable $\mathrm{P}=\mathrm{O}---\mathrm{Al}$ interactions. Thus, more stable self-assembled structures are obtained when the size of these groups is decreased. The complex 2 has only one phenyl ring on the phosphorus atom. This structural change decreases dramatically its solubility. This compound is only soluble in the presence of a coordinating molecule. It can be explained by the formation of stable oligomeric structures with $\mathrm{P}=\mathrm{O}---\mathrm{Al}$ interactions which are disassembled by methanol. $\mathrm{FAB}^{+}$mass spectrometry provided evidence for oligomeric structures (Figure 6). Signals up to the tetramer fragment $(\mathrm{m} / \mathrm{z}=2984.2)$ are detected, showing the stability of the -[Al-O-P=O]backbone toward $\mathrm{FAB}^{+}$mass spectrometry conditions.

Figure 6. $\mathrm{FAB}^{+}$mass spectrum of the complex 2 . The different fragments

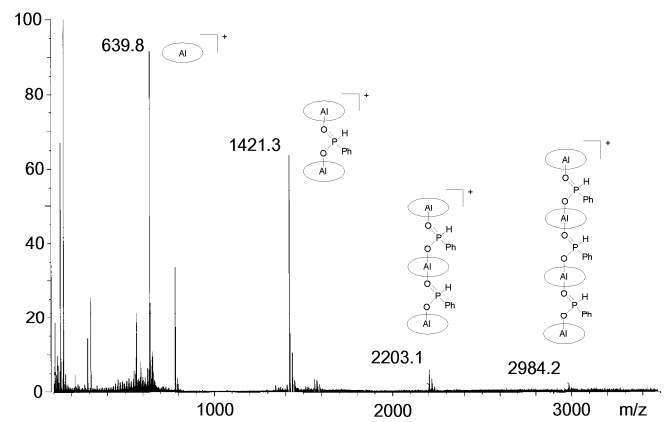

observed are schematically represented.

In summary, aluminum (III) meso-tetraphenyl porphyrin complexes axially bonded to phosphinate anions have been prepared and characterized. These compounds are versatile building blocks to obtain 1-D self-assembled structures. According to the solvent and the size of the anion, two self-assembly pathways are possible to give supramolecular chains like $[\mathbf{1}+\mathbf{e t h a n o l}]_{\infty}$ or self-assembled structures with $\mathrm{P}=\mathrm{O}---\mathrm{Al}$ interactions.
Acknowledgment. We are grateful to the Centre National de la Recherche Scientifique and the Ministère de l'Education Nationale de France for financial support.

Supporting information available: General experimental details, full synthetic procedure and characterization of the compounds 1 and 2, estimation of the $K_{\text {assoc }}$ for $\mathbf{1}$, crystallographic data for $[1+\text { ethanol }]_{\infty}$.

* To whom correspondence should be addressed. E-mail: sricheter@univ-montp2.fr.

† Laboratoire de Chimie Moléculaire et Organisation du Solide.

\$ Institut Européen des Membranes.

(1) Lehn, J. -M. Supramolecular Chemistry. Concepts and Perspectives, VCH, Weinheim, 1995.

(2) (a) Bystrova, M. I.; Mal'gosheva, I. N.; Krasnovskii, A. A. Mol. Biol. 1979, 13, 582-594. (b) Balaban, T. S.; Holzwarth, A. R.; Schaffner, K.; Boender, G. -J.; de Groot, J. J. M. Biochemistry 1995, 34, 15259-15266.

(3) (a) For examples, see: Chambron, J. -C.; Heitz, V.; Sauvage, J. -P. In The Porphyrin Handbook; Kadish, K. M., Smith, K. M., Guillard, R., Eds.; Academic Press: Orlando, 2000; Vol. 6, Chapter 40, pp 1-42. (b) Goldberg, I. Cryst. Eng. Comm. 2002, 4, 109-116. (c) Drain, C. M. Russell, K. C; Lehn, J. -M. Chem. Commun. 1996, 337-338. (d) Drain, C. M.; Nifiatis, F.; Vasenko, A.; Batteas, J. D. Angew. Chem., Int. Ed. 1998, 37, 2344-2347. (e) Wang, Z.; Medforth, C. J.; Shelnutt; J. A. J. Am. Chem. Soc. 2001, 126, 15954-15955. (f) Balaban, T. S.; Goddard, R.; Linke-Schaetzel, M.; Lehn, J. -M. J. Am. Chem. Soc. 2003, 125, 4233-4239. (g) Balaban, T. S.; Bhise, A. D.; Fischer, M.; Linke-Schaetzel, M.; Roussel, C.; Vanthuyne, N. Angew. Chem., Int. Ed. 2003, 42, 2140-2144. (h) Balaban, T. S.; Linke-Schaetzel, M.; Bhise, A.D.; Vanthuyne, N. Roussel, C. Eur. J. Org. Chem. 2004, 3919-3930.

(4) (a) Michelsen, U.; Hunter, C. A. Angew. Chem., Int. Ed. 2000, 39 764-767. (b) Haycock, R. A.; Hunter, C. A.; James, D. A. Michelsen, U.; Sutton, L. R. Org. Lett. 2000, 2, 2435-2438. (c) Tsuda, A.; Nakamura, T.; Sakamoto, S.; Yamaguchi, K.; Osuka, A. Angew. Chem., Int. Ed. 2002, 41, 2817-2821. (d) Twyman, L. J.; King, A. S. H. Chem. Commun. 2002, 910-911. (e) Furutsu, D. Satake, A.; Kobuke, Y. Inorg. Chem. 2005, 44, 4460-4462. (f) Takahashi, R.; Kobuke, Y. J. Org. Chem. 2005, 70, 2745-2753.

(5) (a) For examples, see: Sanders, J. K. M.; Bampos, N.; ClydeWatson, Z.; Darling, S. L.; Hawley, J. C.; Kim, H. -J.; Mak, C. C.; Webb, S. J. In The Porphyrin Handbook; Kadish, K. M., Smith, K. M., Guillard, R., Eds.; Academic Press: New York, 2000; Vol. 3, pp 1-48. (b) Stulz, E.; Scott, S. M.; Ng, Y. -F.; Bond, A. D.; Teat, S. J.; Darling, S. L.; Feeder, N.; Sanders, J. K. M. Inorg. Chem. 2003, 42, 6564-6574.

(6) (a) Sugimoto, H.; Kimura, T.; Inoue, S. J. Am. Chem. Soc. 1999 121, 2325-2326. (b) Konishi, K.; Aida, T.; Inoue, S. J. Org. Chem. 1990, 55, 816-820. (c) Hirai, Y.; Aida, T.; Inoue, S. J. Am. Chem. Soc. 1989, 111, 3062-3063.

(7) Kumar, P. P.; Maiya, B. G. New J. Chem. 2003, 27, 619-625.

(8) Davidson, G. J. E.; Tong, L. H.; Raithby, P. R.; Sanders, J. K. M. Chem. Commun. 2006, 3087-3089.

(9) Crystal data for 1.EtOH $\left(\mathrm{C}_{58} \mathrm{H}_{44} \mathrm{~N}_{4} \mathrm{O}_{3} \mathrm{PAl}\right): M_{\mathrm{w}}=902.97$, monoclinic, space group $P 12_{1} / c 1$ (No. 14), $a=12.8820$ (4) $\AA, b=$ 26.0619(7) $\AA, c=15.0590(4) \AA, \beta=111.15(2)^{\circ}, V=4715.19(70)$ $\AA^{3}, Z=4, d_{\text {calcd }}=1.268$ g.cm $3, T=173 \mathrm{~K}, \lambda(\mathrm{Mo} \mathrm{K} \alpha)=0.71073 \AA$, $\mu(\mathrm{Mo} \mathrm{K} \alpha)=0.128 \mathrm{~mm}^{-1}, 87791$ reflections collected, 15579 unique reflections, $\mathrm{R} 1_{\text {obsd }}$ for $[I>2 \sigma(I)]=0.1037, \mathrm{wR} 2_{\text {all }}\left(F^{2}\right)=0.1017$ for all data, GOF on $\mathrm{F}^{2}=1.301$, trans. coeff. $=0.980-0.990$.

(10) Mitra, A.; Parkin, S.; Atwood, D. A. Inorg. Chem. 2006, 45, 39703975 .

(11) (a) Gardner, M.; Guerin, A. J.; Hunter, C. A.; Michelsen, U.; Rotger, C. New J. Chem. 1999, 309-316. (b) Ma, C. T. L.; MacLachlan, M. J. Angew. Chem., Int. Ed. 2005, 44, 4178-4182.

(12) Kaisu, Y.; Misu, N.; Tsuji, K.; Kaneko, Y.; Kobayashi, H. Bull. Chem. Soc. Jpn. 1985, 58, 103-108.

(13) Gouterman, M.; Holten, D.; Lieberman, E. Chem. Phys. 1977, 25, 139-153.

(14) MALDI-TOF mass spectrometry was not so efficient to detect oligomeric fragments because disassembly processes should occur during the laser photoexcitation of the porphyrin. See ref. $3 \mathrm{f}$.

(15) The $\mathrm{K}_{a s s o c}$ was estimated on the assumption that the concentration of the free complex $\mathbf{1}$ is $<20 \%$ of the total concentration $24 \mu \mathrm{M}$. See the Supporting Information. 
Aluminum(III) meso-tetraphenylporphyrins axially bonded to phosphinate anions have been synthesized and structurally characterized. According to the size of the phosphinate anion and the solvent used, these compounds are able to selfassemble in two different manners as it is demonstrated by X-ray analysis, $\mathrm{FAB}^{+}$mass spectrometry and NMR and UVvisible spectroscopy.
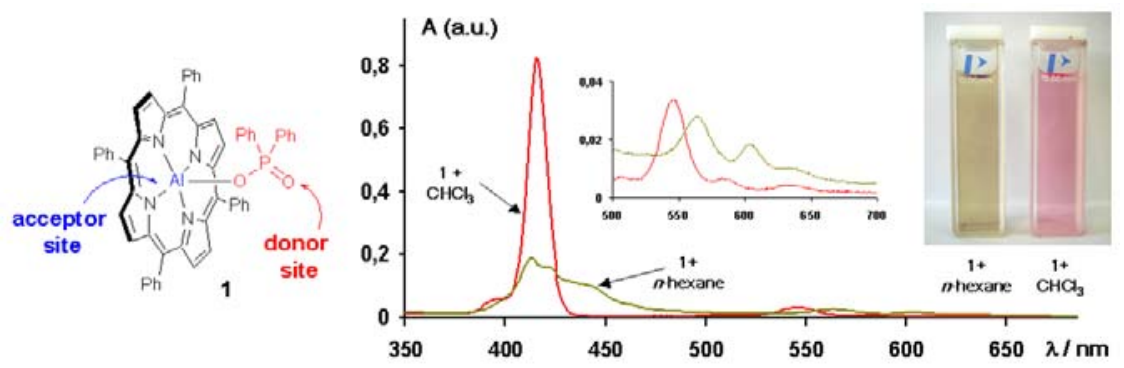